DOI: 10.32089/WBH.PHW.2021.2(276).0007

orcid.org/0000-0003-3580-604X

\author{
DANIEL Kiper
}

Katolicki Uniwersytet Lubelski

\title{
Polacy w armii amerykańskiej podczas konfliktu zbrojnego na Kubie w 1898 r. (szkic problemu)
}

\begin{abstract}
The article deals with the problems associated with Polish immigrants who served in the US Army during the armed conflict in Cuba in 1898. Due to the current state of research, we can only roughly estimate the number of Poles involved in the Spanish-American war. A variety of articles concerning the subject appeared in the contemporary Polish press, based on which attempts were made to outline the general circumstances behind Polish recruitment into the US Army as well as other issues related to, inter alia, military careers, military pastoral care and collective memory of the war.
\end{abstract}

Ogrom trudności czeka historyka, który podejmie próbę ustalenia choćby przybliżonej liczby obywateli amerykańskich polskiego pochodzenia biorących udział w kampaniach wojennych Stanów Zjednoczonych lat 1898-1902. Podstawowym problemem uniemożliwiającym opracowanie takiej listy był nagminny proceder przyjmowania nowych nazwisk. ${ }^{1}$ Praktyka ta stała się popularna szczególnie $\mathrm{w}$ drugim pokoleniu imigrantów, którego przedstawiciele, asymilując się do kultury amerykańskiej, szybciej i chętniej zmieniali personalia niż pokolenie ich rodziców. Gdy redaktorzy Dziennika Chicagoskiego usiłowali wyłowić Polaków spośród ofiar bitwy o Santiago byli przekonani, że „więcej jeszcze Polaków ukrywa się pod nazwiskami

\footnotetext{
1 „Poskutkowało, Polak w Ameryce, kwiecień 28, 1898, 1; „Kronika wojskowa,” Sztandar, lipiec 14, 1898, 3.
} 
irlandzkimi, niemieckimi itp."2 Jan Wlekliński, jeden z uczestników wojny ${ }^{3}$, usiłujący policzyć swoich rodaków w obozie wojskowym w Jacksonville napisał: „Jest tutaj ich więcej[,] ale jak sami powiadają[,] nie uważają się za Polaków". ${ }^{4}$ Nawet ci, którzy postanowili zachować dotychczasową tożsamość, rozsiani byli po rozmaitych formacjach wojskowych (w marynarce, wojskach lądowych, służbach sanitarno-porządkowych itp.).

Trudno dzisiaj mierzyć się z tym wyzwaniem, nawet przy ułatwieniach $\mathrm{w}$ dostępie do materiałów przechowywanych $\mathrm{w}$ archiwach amerykańskich, gdyż w rejestrach wojskowych nie brano pod uwagę pochodzenia etnicznego rekrutów. Dodatkowym czynnikiem utrudniającym odszukanie we wspomnianych materiałach Polaków są błędne zapisy wielu nazwisk, notowanych przez urzędników amerykańskich niedokładnie i w pośpiechu. ${ }^{5}$ Mając do dyspozycji fragmenty dokumentacji zapisane $\mathrm{w}$ formie cyfrowej, jesteśmy w stanie ustalić jedynie w dużym uogólnieniu częstotliwość występowania osób o polskich korzeniach w armii amerykańskiej z poszczególnych stanów. Przydatnym narzędziem dla skrupulatnych badaczy mogą być m.in. rejestry zgromadzone w Spanish-American War Service Record Index ${ }^{6}$, zawierające wykazy personaliów dziesiątków tysięcy żołnierzy biorących udział w tej wojnie. Na podstawie tego jednego źródła (wyławiając $\mathrm{z}$ niego polskie nazwiska) można założyć, że największy odsetek Polaków zwerbowanych do amerykańskiej armii podczas omawianego konfliktu pochodził z Wisconsin (112) i Nowego Jorku (102). Zastanawiający jest stosunkowo niewielki procent rekrutów z Illinois (40), gdzie mieszkało najwięcej osób polskiego pochodzenia w tym czasie. Dużo większe zainteresowanie wojną wykazali Polacy z Minnesoty (53). Niewielka liczba polsko brzmiących nazwisk - w stosunku do liczby ludności - pojawiała się w rejestrach takich stanów, jak Pensylwania (15), Ohio (15), Missouri (16), Michigan (17), Indiana (8) czy Iowa (8). ${ }^{7}$

Istotną częścią bazy źródłowej pomocnej przy odtwarzaniu przebiegu rekrutacji prowadzonej w trakcie wojny $1898 \mathrm{r}$. jest prasa polonijna. Zaznaczyć jednak trzeba, że z punktu widzenia medialnego oddziaływania próby ustalania oraz informowania opinii publicznej o rzeczywistej liczbie

\footnotetext{
2 „Zabici i ranni pod Santiago," Dziennik Chicagoski, lipiec 8, 1898, 1.

3 „Sprawy osobiste," Dziennik Chicagoski, luty 27, 1900, 4.

4 Jan Wlekliński, „Z obozu,” Dziennik Chicagoski, sierpień 8, 1898, 2.

5 Problem błędnego zapisu nazwisk polskich, m.in. przez amerykańskich urzędników, podnoszony był zresztą od dawna w polonijnej prasie, zob. m.in. „Początek dzieła,” Ogniwo, sierpień 3, 1880, 1.

6 „Spanish-American War Service Record, Index," Fold3 ${ }^{\circ}$, dostęp listopad 14, 2020, https:// www.fold3.com/browse/hyABSb3KgLle5B31pgnfgkQ11.

7 Ibid.
} 
polskich ochotników nie należały do priorytetów. Dla przywódców polonijnych bardziej liczył się przekaz perswazyjny, mający wzmocnić społeczno-polityczną pozycję instytucji etnicznych. Symboliczną wartość dla opinii publicznej stanowiło wykazanie pierwszeństwa w akcie wyzwolenia Kuby, które miało wyróżnić i podnieść wartość nieanglosaskich bojowników w oczach własnych i społeczeństwa amerykańskiego. Artykuły umieszczane w prasie etnicznej - w których publicyści doszukiwali się pierwszeństwa „swoich” żołnierzy w kluczowych momentach toczącej się wojny - pokazują, jak ważna była to dla nich sprawa. ${ }^{8}$ Dziennikarze polonijni również ulegli tej pokusie. Pierwszy strzał oddany w wojnie przypisywano polskiemu marynarzowi Stanisławowi Kempińskiemu, służącemu na kanonierce USS "Nashville". Polak posługujący się obcym nazwiskiem miał zginąć także podczas eksplozji na okręcie USS „Maine”."10

O ile można mieć poważne zastrzeżenia do przedstawianych doniesień, o tyle $\mathrm{z}$ uznaniem należy odnotować wysiłki dziennikarzy polonijnych zmierzające do oszacowania realnej skali zaangażowania Polaków w wydarzenia wojenne roku 1898 . Jeszcze w czasie trwania konfliktu redaktorzy Narodu Polskiego podnieśli ambitne hasło ustalenia liczby żołnierzy, w których płynęła polska krew. ${ }^{11}$ Zadanie to przerosło najwyraźniej możliwości redakcji, skoro nigdy nie wrócono do sprawy, pozostawiając pytanie o liczbę polskich ochotników oraz żołnierzy regularnej armii walczących w szeregach USA bez odpowiedzi. Chociaż materiały dziennikarskie nie mogą dostarczyć informacji do gruntownego i rzetelnego odtworzenia listy Polaków służących pod sztandarem amerykańskim, to jednak wciąż pozostają wartościowym źródłem rozmaitych stanowisk wobec konfliktu. Publikowane na łamach pism polonijnych treści urzędowo-statystyczne stanowią bogatą bazę faktograficzną, dającą podstawę do formułowania wniosków i ocen odnoszących się do zaangażowania wojennego grup etnicznych w USA. Materiał prasowy, ukazujący fragmenty wojennych biografii żołnierzy, pozwala również na uchwycenie ważnych społecznych kontekstów toczącego się konfliktu w perspektywie osobistych doświadczeń żołnierzy. Reakcje na kryzys kubański znalazły odzwierciedlenie w wielu wymiarach życia publicznego społeczności imigranckich Nowego Świata, nie tylko w prasie, ale również w literaturze, sztuce, życiu

\footnotetext{
8 Matthew F. Jacobson, Special Sorrows. The Diasporic Imagination of Irish, Polish, and Jewish Immigrants in the United States (Cambridge-London: Harvard University Press, 1995), 157-158.

9 „Pierwszy strzał”, Zgoda, lipiec 14, 1898, 1. Kępiński był synem zasłużonego członka Związku Narodowego Polskiego Walentego Kępińskiego.

10 Jeśli wierzyć dziennikarzom polonijnym, był nim Franciszek Tuszyński z Detroit, który zmienił nazwisko na Fisher, zob. „Z niw polskich w Ameryce,” Wiarus, marzec 17, 1898, 4.

11 „Policzmy naszych wojaków," Naród Polski, lipiec 14, 1898, 1.
} 
organizacyjnym. ${ }^{12}$ Konflikt wzbudzał silne emocje w skupiskach polonijnych, zmuszając czołowe wychodźcze ugrupowania do zajęcia stanowiska wobec polityki imperialnej Stanów Zjednoczonych. Mimo iż nie uzgodniono jednolitego stanowiska co do konieczności udziału osób polskiego pochodzenia w wojennej eskapadzie, większość organizacji polonijnych poddała się narastającemu uniesieniu wojennemu, zachęcając rodaków do walki. Podczas naboru ochotników młodzi Polacy zgłaszali się do punktów werbunkowych $\mathrm{z}$ własnej inicjatywy bądź za namową liderów.

Niniejszy tekst jest próbą opisania kilku istotnych faktów związanych z rekrutacją i służbą Polaków w amerykańskich formacjach wojskowych podczas wojny na Kubie w 1898 r. Temat ten nie był dotychczas przedmiotem pogłębionych studiów. W polskiej historiografii wojskowej brakuje także opracowań na temat udziału osób polskiego pochodzenia w wydarzeniach wojennych na Filipinach w latach 1898-1902. Mogłyby one znacznie poszerzyć pole obserwacji grup etnicznych w Stanach Zjednoczonych reagujących na politykę zagraniczną tego państwa.

Zasadniczych przyczyn wojny amerykańsko-hiszpańskiej, a w konsekwencji także podboju Filipin, należy szukać przede wszystkim w czynnikach ekonomicznych, chociaż dużą rolę odegrały także pobudki polityczne oraz uwarunkowania psychospołeczne. ${ }^{13}$ Pod koniec XIX stulecia intensywnie rozwijająca się gospodarka Stanów Zjednoczonych osiągnęła na wielu płaszczyznach limit możliwości rozwojowych. Podbój i zagospodarowanie zachodnich terenów kontynentu wyznaczyły naturalne granice ekspansji dla elit finansowych tego kraju. Po skolonizowaniu Zachodu poszukiwano nowych terenów dla inwestycji. ${ }^{14} \mathrm{~W}$ tym samym czasie ustalony od niemal trzech stuleci postfeudalny system ekonomiczny krajów Ameryki

12 „Ślub. Opowieść na tle prawdziwego zdarzenia z ostatniej wojny hiszpańskiej,” Dziennik Chicagoski, wrzesień 10, 1898, 6; Stefan Barszczewski, Cuba Libre! Melodramat w 5-ciu odsłonach, osnuty na tle wojny hiszpańsko-amerykańskiej i Sokolstwa Polskiego w Ameryce (Chicago: b.w., 1899); Jacobson, Special, 144-145; Arlow W. Andersen, Rough Road to Glory. The Norwegian-American Press Speaks Out on Public Affairs, 1875 to 1925 (Philadelphia: Balch Institute Press, 1990), 71-89.

13 Samuel F. Bemis, A Diplomatic History of the United States (New York: Holt, 1963), 432450; Richard Hofstadter, "Manifest Destiny and the Philiphines," w American Imperialism in 1898, red. Theodore P. Greene (Boston: D.C. Heath and Company, 1955), 54-56; Walter LaFeber, The Cambridge History of American Foreign Relations, t. 2, The American Search for Opportunity 1865-1913 (Cambridge: Cambridge University Press, 1995), 129, 139-145.

14 W połowie lat dziewięćdziesiątych XIX w. USA były głównym odbiorcą towarów eksportowanych z Kuby (84\%). Przyjmuje się, że kraj ten kupował 94\% wyprodukowanego na wyspie cukru, zob. Piotr Olender, Wojna amerykańsko-hiszpańska na morzu 1898 r. (Warszawa: Lampart, 1995), 7-8. Wartość wymiany handlowej między Stanami Zjednoczonymi a Kubą na przełomie lat osiemdziesiątych i dziewięćdziesiątych XIX w. osiągnęła sumę $100 \mathrm{mln}$ dolarów, co stanowiło ok. 7\% całego obrotu zagranicznego USA, zob. Wiesław Dobrzycki, 
Łacińskiej, będących pod panowaniem hiszpańskim i portugalskim, stawał się coraz mniej wydolny i dopasowany do kapitalistycznych realiów ówczesnego świata. Ludności tamtejszych terenów, poddanej rabunkowej eksploatacji gospodarczej i trzymanej w ryzach przez system urzędniczo-wojskowy, coraz bardziej doskwierał ten stan rzeczy. Aktywne politycznie grupy przywódcze, przesiąknięte europejskimi ideologiami narodowowyzwoleńczymi, regularnie chwytały za broń, by walczyć o niepodległość. Krwawo tłumione powstania wzmagały opór m.in. dzięki życzliwej neutralności rządu Stanów Zjednoczonych. W metropoliach amerykańskich bojownicy o wolność Kuby mogli się swobodnie organizować i zaopatrywać w bron. Do połowy lat dziewięćdziesiątych XIX w. Waszyngton nie był zainteresowany otwartym konfliktem z Hiszpanią, obawiając się konsekwencji kryzysu dyplomatycznego, jaki mogłaby wywołać zbrojna interwencja na Kubie. Gdy ostatecznie zdecydowano się na użycie siły wobec Hiszpanii, prawdopodobieństwo militarnej reakcji państw europejskich było już niewielkie. U progu 1898 r. USA były gotowe przejąć kontrolę nad Kubą, Puerto Rico i Filipinami, licząc nie tylko na zyski finansowe, ale także transmisję wartości republikańskich do krajów latynoamerykańskich.

Wejście na drogę konfliktu zbrojnego stało się punktem zwrotnym amerykańskiej polityki zagranicznej, przekreślając ostatecznie zainicjowaną przed laty politykę izolacjonizmu, sformułowaną przez prezydenta Jamesa Monroe’a. Zastąpiła ją (nie bez oporów ${ }^{15}$ ) idea tzw. „objawionego przeznaczenia", która zmierzała do podporządkowywania i ustanowienia nowych porządków w tych sąsiednich krajach, które w przekonaniu amerykańskich elit politycznych były źle zarządzane bądź opóźnione cywilizacyjnie. ${ }^{16}$ Narastającemu poczuciu misji dziejowej towarzyszył masowy, patriotyczny entuzjazm, który skutecznie wyciszył i rozładował społeczne protesty wewnątrz kraju, nasilające się od kryzysu roku $1893 .{ }^{17}$ Taktykę łagodzenia napięć społecznych poprzez masowe promowanie postaw patriotycznych, która miała miejsce w latach dziewięćdziesiątych XIX w., dostrzegali i nazywali po imieniu niektórzy przedstawiciele inteligencji polonijnej. Redaktor Telegrafu,

Historia stosunków międzynarodowych w czasach nowożytnych 1815-1945 (Warszawa: Wyd. Naukowe Scholar, 1996), 215.

15 Przyjęcie idei New Manifest Destiny poprzedziła ostra debata polityczna w Kongresie. Przeciwnicy polityki imperialnej skupieni pod wodzą Thomasa Bracketta Reeda dowodzili, że modelu demokracji amerykańskiej nie można pogodzić z kolonializmem. Zob. szerzej o tym, m.in. E. Berkeley Tompkins, Anti-Imperialism in the United States: The Great Debate 1890-1920 (Philadelphia: University of Pennsylvania Press, 1970), 84-94; Barbara Tuchman, Wyniosła wieża. Świat przed pierwsza wojna 1890-1914 (Warszawa: Bellona, 1997), 129-175.

16 Albert K. Weinberg, Manifest Destiny. A Study of Nationalist Expansionism in American History (Chicago: Quadrangle Books, 1963), 273-275.

17 Ibid., 59. 
Mieczysław J. Szameit, obserwując życie społeczno-polityczne Ameryki, w publikacji pt. „Marzyciele” opisał nowe tendencje w zakresie prowadzonej edukacji szkolnej: „Na kilka lat przed paniką roku 1893, wielu dobrze myślących i nader miłych obywateli stało się nagle wielce przepełnionymi patriotyzmem. Spostrzegli z przerażeniem, że młoda generacja nie jest patriotyczna. Nie mogąc sobie wytłumaczyć tego stanu rzeczy postanowili propagować ducha patriotyzmu w publicznych szkołach. W tym celu pewne dni były przeznaczone na naukę patriotyzmu. Dzieciaków uczono, że ich ojczyzna była największym krajem na ziemi, jedynym w którym lud miał głos w rządzie i inne podobne świecące jasno spostrzeżenia, mniej lub więcej prawdziwe. Przyznać trzeba, że tego rodzaju patriotyczna praca wydała nader porządny owoc". ${ }^{18}$ Celnie spuentował ówczesne nastroje amerykański historyk John D. Hicks, pisząc: „Ameryka wiosną 1898 r. była gotowa na każdą wojnę, a zapału tego kraju nie można było zmarnować”. ${ }^{19}$

Imponujący potencjał gospodarczy w niewielkim stopniu przełożył się na siłę militarną USA. Już pierwsze tygodnie wojny pokazały poważne problemy z organizacją wojsk lądowych, a powszechny, planowany pobór 200 tys. ochotników prowadzony był nieudolnie. Także wiele późniejszych operacji militarnych obfitowało $\mathrm{w}$ chaotyczne działania i nieprzemyślane decyzje. Jedyną formacją, która przedstawiała znaczącą wartość bojową, była flota. ${ }^{20}$ Mimo że decydujące o losach wojny starcia miały miejsce na morzu, znaczna większość poległych zginęła na lądzie. Wojna oficjalnie rozpoczęła się 25 kwietnia 1898 r. $^{21}, 69$ dni po eksplozji i zatonięciu okrętu liniowego USS „Maine” w Zatoce Hawańskiej. Wzięło w niej udział ok. 300 tys. żołnierzy, z czego 280 zostało zabitych w wyniku działań wojennych, 616 zmarło $\mathrm{z}$ powodu odniesionych ran, zaś ponad 2,5 tys. zmarło na skutek chorób zakaźnych spowodowanych tropikalnym klimatem, złymi warunkami sanitarnymi oraz niezdrowym jedzeniem. ${ }^{22}$ Liczba zmobilizowanych żołnierzy była

18 Mieczysław J. Szameit, „Marzyciele, Telegraf, kwiecień 20, 1898, 2.

19 John D. Hicks, A Short History of American Democracy (Boston: Houghton Mifflin Company, 1949), 605.

20 Robert Kłoskowicz, U.S. Marines jako narzędzie polityki zagranicznej Stanów Zjednoczonych (Kraków: Wyd. Uniwersytetu Jagiellońskiego, 2008), 67.

$21 \quad$ Faktycznie operacje wojskowe trwały już od 22 kwietnia.

22 Ralph M. Baker i Spencer C. Tucker, „United States Army,” w The Encyclopedia of the Spanish-American and Philippine Wars. A Political, Social and Military History, red. Spencer C. Tucker, t. 1-3 (Santa Barbara: ABC-CLIO, 2009), 3:664; zob. Bogusław W. Wind, Santiago 1898 (Warszawa: Bellona, 1995), 175-179; „Straty w wojnie i po wojnie,” Kurier Polski, wrzesień 2, 1898, 1; „Straty w wojnie i po wojnie,” Nowe Życie, wrzesień 17, 1898, 1. Największy rozgłos zyskała specjalna komisja powołana 26 IX 1898 r. do zbadania afery tzw. beef controversy, która dotyczyła sprawy dostarczania żołnierzom walczącym na wojnie niskiej jakości wołowiny, chemicznie modyfikowanej, źle zakonserwowanej i zepsutej. W efekcie okazała 
nieporównywalnie mniejsza od liczby żołnierzy biorących udział w wojnie secesyjnej, ale też należy podkreślić, że w 1898 r. nie wprowadzono powszechnego obowiązku służby wojskowej. Wiele jednostek lądowych, wystawionych $\mathrm{w}$ dwóch turach, nigdy nie dotarło do strefy wojennej. ${ }^{23}$ Mógł mieć rację jeden z publicystów Kuriera Polskiego, kiedy donosił „że żołnierz pod Jacksonville [obóz wojskowy] więcej wycierpiał, bardziej się wyniszczył, niż ci, którzy na parę tygodni na pole bitwy posłano, a potem do kraju przywieziono". ${ }^{24}$

Regularna armia USA przed wybuchem wojny liczyła zaledwie 28183 żołnierzy zgrupowanych w 25 pułkach piechoty, rozproszonych po całym terytorium Stanów Zjednoczonych. ${ }^{25}$ Stanowiło to niewielką liczbę w porównaniu ze standardami europejskimi. W czasie działań zbrojnych rząd dysponował 60 tys. żołnierzy. Niewiele więcej, bo 65 tys., liczyła armia amerykańska rok później, po zakończeniu działań wojennych na Kubie. ${ }^{26} \mathrm{Naj}$ większe oddziały armii zasilane były ochotnikami werbowanymi na mocy specjalnej ustawy mobilizacyjnej. Większość z nich pochodziła z Gwardii Narodowej składającej się głównie z przedstawicieli milicji stanowych. Początkowo było ich 125 tys., następnie zwiększono ich liczbę do 270 tys. Ochotnicy zasilili także specjalne jednostki, oprócz słynnego oddziału Rough Riders, także marynarkę wojenną oraz inne formacje pomocnicze, m.in. US Coast Signal Service, US Marine Corps i US Army Nurse Corps. Armię regularną i ochotniczą podzielono na siedem korpusów. W czerwcu $1898 \mathrm{r}$. powołano do życia dodatkowo ósmy korpus. Ze względu na stosunkowo krótki czas trwania zmagań nie wszystkie zostały w pełni zorganizowane. Każdy korpus miał być podzielony na trzy dywizje, każda w sile ok. 10 tys. żołnierzy, dywizje z kolei na trzy brygady. Brygada składała się z minimum trzech regimentów. Regimenty armii regularnej podzielono na kompanie

się ona szkodliwa dla zdrowia, powodując liczne choroby i zgony. Komisja uznała zarzuty za bezpodstawne, jednak nagłośniony skandal przyczynił się do pierwszych prób uregulowania pod względem sanitarnym procesu przetwórstwa mięsnego w USA. Zob. Report of the Commission Appointed by the President to Investigate the Conduct of the War Department in the War with Spain, t. 1-8 (Washington: Government Printing Office, 1900); Donald H. Dyal, Historical Dictionary of the Spanish-American War (Westport: Greenwood Press, 1996), 111; „Mięso dla wojsk," Dziennik Chicagoski, wrzesień 19, 1900, 1.

23 Nie bez przyczyny Walter Millis w swoim przenikliwym studium napisał, że wojna Stanów Zjednoczonych z Hiszpanią w 1898 r. była parodią wcześniejszych wojen, a także tych, które nastąpiły po niej. Walter Millis, The Martial Spirit. A Study of Our War with Spain (New York: Viking Press, 1965), XII.

24 „Nasi żołnierze powracają,” Kurier Polski, wrzesień 5, 1898, 1. Większość z żołnierzy trzymano jako rezerwę na wypadek bezpośredniego zagrożenia kraju; Olender, Wojna, 33.

25 Baker i Tucker, United, 663-664.

26 „Słówko o militaryzmie,” Dziennik Chicagoski, październik 20, 1900, 4. 
według porządku alfabetycznego; poza wyjątkami zostały one rozdysponowane po obozach wojskowych w czterech punktach: Chickamauga (Georgia), Nowy Orlean (Luizjana), Mobile (Alabama) oraz Tampa (Floryda). ${ }^{27}$ Oprócz tego na terenie całego terytorium USA rozsiane były rozmaite typy obozów ruchomych dla ochotników, wolontariuszy, służby porządkowej itp. ${ }^{28}$ Do ich budowy wykorzystywano miejsca użyteczności publicznej: miejsca targowe, pola wyścigowe, hale wystawowe.

Najbardziej wyróżniającą się formacją militarną reprezentowaną przez Polaków w wojnie amerykańsko-hiszpańskiej była Gwardia Kościuszki z Milwaukee. Jej historia sięga 1874 r., gdy grupa imigrantów z Poznańskiego postanowiła powołać do istnienia towarzystwo wojskowe przy parafii św. Stanisława. ${ }^{29}$ Należeli do niego m.in. August Rudziński, Michał Kłos, Józef Słupecki, Antoni Szczerbiński, August Kudziński, Aleksander Cyzmer i Bernard Kołpacki. ${ }^{30} 14$ września tr. ówczesny gubernator stanu Wisconsin przyjął organizację w poczet milicji miejskiej, zaopatrując jej członków w broń oraz mundury. Trzy lata później, kiedy komendę nad Gwardią objął Józef Borchardt, uczestnik wojny secesyjnej, „Gwardia Kościuszki zaczęła brać udział w manewrach wojsk i miała sposobność wyróżniania się korzystnie między kompaniami milicji innych narodowości”."31 To właśnie dzięki staraniom Borchardta, jak podkreślano, „udało się zrobić z Gwardii Kościuszki towarzystwo mogące być wzorem każdemu towarzystwu polskiemu w Ameryce". ${ }^{32}$ W 1889 r. na kilka miesięcy komendę nad towarzystwem objął Roman Czerwiński, a następnie mjr Edward Słupecki, który pełnił tę funkcję przez cztery lata. ${ }^{33} \mathrm{~W} 1894 \mathrm{r}$. Gwardią dowodził Tadeusz Wild, syn znanego księgarza lwowskiego Karola Wilda. Organizacja, zmieniając swoją strukturę, weszła w skład milicji stanu Wisconsin

\footnotetext{
27 Correspondence Relating to the War with Spain: Including in the Philippines Islands and the China Relief Expedition, t. 1 (Washington: Government Printing Office, 1902), 509.

28 Więcej na temat struktury obozów wojskowych z roku 1898 zob. Paul G. Pierpaoli, "Camps, U.S. Army," w The Encyclopedia of the Spanish-American and Philippine Wars, $1: 94$.

29 Wacław Kruszka, Historia polska w Ameryce. Początek, wzrost i rozwój dziejowy osad polskich w Pótnocnej Ameryce (w Stanach Zjednoczonych i Kanadzie), t. 7 (Milwaukee: Drukiem Spółki Wydawniczej Kuriera, 1906), 50.

30 „Gwardia Kościuszki, Dziennik Chicagoski, wrzesień 6, 1899, 2; „Ś.p. Bernard Kołpacki,” Dziennik Chicagoski, grudzień 31, 1900, 2; „Z Milwaukee, Wis.”, Dziennik Chicagoski, maj 18, 1903, 2.

31 „Gwardia Kościuszki,” Dziennik Chicagoski, wrzesień 6, 1899, 2. Zob. W. Michalak, „Korespondencje «Ogniwa»," Ogniwo, listopad 26, 1879, 2.

32 „Milwaukee," Zgoda, wrzesień 9, 1885, 3.

33 „Gwardia Kościuszki," Kurier Polski, grudzień 5, 1894, 2.
} 
(Wisconsin National Guard) jako kompania B. ${ }^{34} \mathrm{~W}$ ten sposób utraciła swój "narodowy” charakter i autonomię, przechodząc pod nadzór gubernatora stanowego. ${ }^{35}$ Zaznaczyć trzeba, że Gwardia Kościuszki, mimo iż wyróżniała się na tle innych paramilitarnych organizacji polonijnych, powielała wzory rozwojowe wielu organizacji etnicznych funkcjonujących wówczas w systemie amerykańskim. ${ }^{36} \mathrm{Na}$ gruncie polonijnym długo była jedynym towarzystwem etnicznie polskim w całych Stanach Zjednoczonych, które otrzymywało subwencję rządową. ${ }^{37}$ Udział w przedsięwzięciach zbrojnych był poniekąd jej obowiązkiem, dlatego też natychmiast po wybuchu wojny amerykańsko-hiszpańskiej blisko połowa gwardzistów (56) zgłosiła się do komisji rekrutujących. ${ }^{38} \mathrm{Z}$ kolei 25 osób zapisało się do innych formacji z Wisconsin, m.in. do 4 Pułku Ochotników. 39

W Chicago działania na rzecz tworzenia oddziału ochotników podjął Piotr Kiołbassa, niekwestionowany autorytet tamtejszej diaspory, działacz polonijny, uczestnik wojny secesyjnej, skarbnik miasta i poseł do legislatury stanowej. ${ }^{40} \mathrm{Już}$ w marcu 1898 r. ogłosił w pismach polonijnych apel do wszystkich Polaków mieszkających w Chicago, by stawili się na spotkanie (Mass Mityng) celem omówienia zasad rekrutacji. ${ }^{41}$ Konieczność demonstracji lojalności wobec przybranej ojczyzny ponowił tuż po ogłoszeniu wojny, zaznaczając, że „chodzi tu o honorowe wystąpienie Polaków”. „Jeżeli wstąpimy w szeregi wojska amerykańskiego” - motywował - „to powinniśmy wystąpić jako organizacja polska, ażeby w wypadku gdybyśmy stanęli wobec nieprzyjaciela w obronie przybranej Ojczyzny naszej, jasno się okazało, że Polacy są i zawsze będą przyjaciółmi wolności i w obronie jej życie ochoczo oddają. ${ }^{42} \mathrm{~W}$ tym samym czasie gubernator Chicago

\footnotetext{
34 „Z niw polskich w Ameryce," Przyjaciel Ludu, październik 14, 1893, 6.

35 „Gwardia Kościuszki," Kurier Polski, wrzesień 24, 1895, 2.
}

36 Za przykład może posłużyć 69 Pułk Milicji Nowojorskiej składający się wyłącznie z Irlandczyków. „Ameryka," Zgoda, marzec 22, 1882, 1.

37 „Sprawozdanie Gwardii Kościuszki w Milwaukee,” Zgoda, wrzesień 9, 1885, 2; dopiero w 1898 r. słyszymy o Polakach w Nanticoke (Pensylwania), którzy rozpoczęli starania o utworzenie oddziału milicji stanowej, zob. „Polacy w Ameryce," Kurier Nowojorski, styczeń 15, 1898, 3.

38 „Notatki," Zgoda, kwiecień 28, 1898, 4.

39 „Polacy w armii Stanów Zjednoczonych," Kurier Polski, sierpień 19, 1898, 2.

40 Franciszek German, „Kiełbassa Piotr,” Polski Słownik Biograficzny 12, (1966-1967): 409-410; Helen Busyn, „Peter Kiolbassa - Maker of Polish America,” Polish American Studies 8, nr 3/4 (1951): 65-84.

${ }^{41}$ „Polacy w Chicago,” Polonia $w$ Ameryce, marzec 25, 1898, 1; James S. Pula, „Kiolbassa Piotr", w The Polish American Encyclopedia, red. James S. Pula (Jefferson: McFarland \& Company, Inc., Publishers, 2011), 227.

42 „Baczność, Dziennik Chicagoski, kwiecień 28, 1898, 1. Zob. „Polscy ochotnicy, Dziennik Chicagoski, kwiecień 23, 1898, 4. 
John R. Tanner, który miał dostarczyć armii 8,4 tys. żołnierzy $y^{43}$, rozpoczął pierwszy nabór, przyjmując do wojska ochotników z milicji stanowej. ${ }^{44}$ Zgromadzenia - na których zjawiało się więcej chętnych, niż było miejsc - organizowano pospiesznie i bez należytej komunikacji z Waszyngtonem. W efekcie „okazało się, że zgłosiło się zbyt wielu ochotników i po większej części trzeba będzie zmniejszyć kompanie o połowę". ${ }^{45}$ Nie sposób dokładnie ustalić w ilu oddziałach ulokowano Polaków. Pewne jest, że dla wielu z nich zabrakło miejsca. $Z$ doniesień prasowych wiemy, że w 1 Pułku Kawalerii Stanu Illinois, składającym się z 12 kompanii, Zygmunt Wiśniewski - jeden z korespondentów - był jedynym Polakiem. ${ }^{46} \mathrm{Z}$ kolei wspomniany już Jan Wlekliński donosił, że w 2 Pułku Piechoty stanu Illinois stacjonującym w Jacksonville było 20 Polaków w kompaniach: A, C, D, F, G, H, I, J, K, L, M. ${ }^{47}$ Polacy byli również w 1 i 16 Pułku Piechoty stanu Illinois (m.in. Kazimierz Lichański w kompanii F). ${ }^{48}$ Jak donosił Tadeusz Wild: „W drugim pułku Illinoiskim pochodzącym z Chicago [...] jest około 20 Polaków, rozrzuconych po różnych kompaniach". ${ }^{49} \mathrm{~W}$ kolejnej turze zaciągu młodzi ponownie zgłosili się do poboru $\mathrm{z}$ nadzieją, że tym razem powstanie „czysto polska kompania.". ${ }^{50}$ Ostatecznie Polacy zostali przydzieleni do kompanii K pod dowództwem kapitana F. L. Pietrowicza. ${ }^{51}$ Oddział nie zdążył jednak wyruszyć na wojnę, co wywołało duże rozczarowanie „młodzieży polskiej". ${ }^{2}$

Wojna uaktywniła także działaczy starszej generacji wychodźczej w Stanach Zjednoczonych, do których umownie możemy zaszeregować emigrantów przybyłych do USA przed 1880 r. O Piotrze Kiołbassie była już mowa wcześniej. Z kolei w Nowym Jorku rolę agitatora wziął na siebie Teodor

43 Ostatecznie w wyniku pierwszego poboru powołano pod broń w stanie Illinois 8048 ochotników, zaś podczas drugiego poboru 4828; zob. „Pobór ochotników,” Dziennik Chicagoski, lipiec 30, 1898, 4.

44 „Do broni,” Dziennik Chicagoski, kwiecień 25, 1898, 1.

45 „Niemiłe dla Tannera,” Dziennik Chicagoski, kwiecień 29, 1898, 1.

46 Zygmunt Wiśniewski, „Listy z teatru wojny,” Dziennik Chicagoski, czerwiec 22, 1898, 2.

47 Jan Wlekliński, „Z obozu, Dziennik Chicagoski, sierpień 8, 1898, 2.

48 „Ofiary wojny," Dziennik Chicagoski, wrzesień 6, 1898, 4; „Powrót pierwszego pułku,” Dziennik Chicagoski, wrzesień 12, 1898, 2.

49 Tadeusz Wild, „Z Jacksonville, Kurier Polski, czerwiec 2, 1898, 1. Zob. „Polacy w obozie pod Jacksonville," Kurier Polski, lipiec 31, 1898, 1.

50 „Polscy ochotnicy, Dziennik Chicagoski, lipiec 1, 1898, 4.

51 „Baczność polscy ochotnicy, Dziennik Chicagoski, lipiec 6, 1898, 4; „Polacy w Chicago,” Dziennik Chicagoski, lipiec 16, 1898, 5.

52 F. L. Pietrowicz, „Do młodzieży polskiej w Chicago,” Dziennik Chicagoski, styczeń 21, 1899, 4. 
Kornobis (od 1871 r. w Ameryce), aktywista Związku Narodowego Polskiego, jeden z założycieli paramilitarnej jednostki Towarzystwo Wolnych Strzelców. ${ }^{53}$ Zwrócił się do władz wojskowych o pozwolenie na formowanie pułku polsko-litewskiego. Kornobis w imieniu swojej organizacji wystąpił z petycją skierowaną na ręce gubernatora, prosząc o upoważnienie na zaciąg do armii. Odpowiedzi udzielił mu sekretarz wojny: „Gub[ernator] [Frank Swett] Black otrzymał list Pański, w którym ofiarujesz swe usługi w wojnie z Hiszpanią. W odpowiedzi nań, pozwolę sobie zaznaczyć, że list Pański został przesłany do adiutanta-generała ${ }^{54}$, który nie omieszka skorzystać $\mathrm{z}$ ofiarowanych mu usług". ${ }^{55}$ Mimo ponawianych starań nie udało się stworzyć wówczas czysto polskiego oddziału, z polskim dowództwem. ${ }^{56} \mathrm{Z}$ kolei w Buffalo na wezwanie miejscowego pisma Polak $w$ Ameryce „polska wiara zgromadziła się gotowa do wojaczki nadspodziewanie licznie, jak niegdyś Krakowiacy na wezwanie Kościuszki”. Pismo zapewniało, że młodzi przyszli „nie z przymusu lecz z wolnej woli i w imię wolności”. ${ }^{57}$ Oddział ochotników sposobił się tam do walki pod okiem M.D. Barczykowskiego.$^{58} \mathrm{~W}$ uformowanym 60 Pułku znalazło się 230 Polaków. ${ }^{59}$ Zapał wojenny objął także skupiska polskie w Filadelfii, gdzie jak pisano, „doświadczony żołnierz, ob. Bulsiewicz stoi na czele dobrze wyszkolonego oddziału kanonierów". ${ }^{60}$ Polacy amerykańscy zaciągali się do armii $\mathrm{w}$ wielu prowincjonalnych miastach, m.in. Stevens Point $^{61}$, Jersey City ${ }^{62}$, Winonie ${ }^{63}$, Bridgeport (Connecticut) ${ }^{64}$, South Bend ${ }^{65}$,

53 Artur Waldo, Sokolstwo przednia straż narodu. Dzieje idei i organizacji w Ameryce, t. 1-4 (Pittsburgh: Sokolstwo Polskie w Ameryce, 1953-1974), 1:134.

54 Czyli osoby pełniącej obowiązki szefa administracji wojskowej.

55 Władysław Nałęcz, Polacy w New Yorku (Toledo: A.A. Paryski, 1910), 104; zob. też „Polacy w Ameryce," Telegraf, marzec 16, 1898, 1.

56 „Pogadanka," Polak w Ameryce, czerwiec 3, 1898, 1; „Polscy ochotnicy, Dziennik Chicagoski, lipiec 9, 1898, 4.

57 [Bez tyt.], Dziennik Chicagoski, kwiecień 29, 1898, 2; zob. też „Walne zebranie. Polacy ofiarują swe siły na usługi rządu i organizują oddział ochotniczy," Echo, czerwiec 28, 1898, 1.

58 „Polski Oddział,” Echo, maj 5, 1898, 2; „Polscy ochotnicy,” Echo, czerwiec 2, 1898, 1.

59 „Kronika miejscowa," Polak w Ameryce, maj 2, 1898, 4.

60 „Rodacy”, Kurier Nowojorski, kwiecień 30, 1898, 1.

61 „Polacy w Ameryce,” Telegraf, maj 11, 1898, 1; „Z osad polskich,” Kurier Polski, czerwiec 29, 1898, 2; „Polacy w Ameryce," Telegraf, lipiec 6, 1898, 1.

62 „Polacy w Ameryce," Ameryka, maj 7, 1898, 4.

63 „Wiadomości miejscowe,” Wiarus, marzec 10, 1898, 7; „Wiadomości miejscowe," Wiarus, kwiecień 28, 1898, 8; „Polscy wojacy w Winony,” Wiarus, maj 12, 1898, 5.

64 „Z niw polskich w Ameryce,” Wiarus, kwiecień 14, 1898, 4; „Polacy w Ameryce,” Telegraf, kwiecień 6, 1898, 1.

65 „Notatki," Zgoda, lipiec 7, 1898, 1. 
St. Louis ${ }^{66}$, Toledo ${ }^{67}$, Cleveland ${ }^{68}$. Do grona ochotników dołączali także Polacy z niewielkich miejscowości, zastrzegając jednak, że „spełniając obowiązek dla przybranej ojczyzny”, chcieliby służyć tylko w „polskich szeregach”. ${ }^{9}$

Można zauważyć, że wielu entuzjastów wojny służyło wcześniej w wojsku. Niektórzy z nich składali przysięgę $\mathrm{w}$ armiach państw zaborczych, inni jak Kiołbassa walczyli w amerykańskiej wojnie domowej. Także synowie weteranów nierzadko wstępowali na drogę służby wojskowej za przykładem ojców. Tadeusz Wild jeszcze przed przybyciem do Stanów Zjednoczonych służył w armii austriackiej, potem zaś zgłosił się do armii amerykańskiej. ${ }^{70}$ Mundur założył także Franciszek Pasternacki ze Stevens Point, „który rwał się do wojska" podczas zaciągu. Był on synem uczestnika wojny secesyjnej o takim samym imieniu, szanowanego obywatela tego miasta. ${ }^{71}$ Epizod wojenny w biografii miał również Antoni Sobieralski, żołnierz wojny francusko-pruskiej. Jego syn Jan walczył pod sztandarem amerykańskim na Filipinach, skąd nie było mu dane wrócić żywym. ${ }^{72}$ Podobnego wyboru dokonał syn hr. Piotra Wodzickiego, jednego z liderów polonijnych w Nowym Jorku, który porzucił pracę w straży pożarnej i zaciągnął się do wojska, po czym został wysłany do Puerto Rico. ${ }^{73} \mathrm{Z}$ kolei wspomniany już Stanisław Kempiński, syn lokalnego przywódcy polonijnego w Duluth - Walentego Kempińskiego - zgłosił się do marynarki wojennej w Nashville. ${ }^{74}$ Wspomnieć można jeszcze zmarłego w czasie wojny 43-letniego J. H. A. Mirowskiego, chicagowskiego miedziorytnika, który spędził dziewięć lat w Indiach Zachodnich. W Chicago dorobił się własnej pracowni „i posiadał wielu przyjaciół między artystami”. ${ }^{75}$

Komisje rekrutacyjne przyjmowały mężczyzn w wieku od 20 do 35 lat po uzyskaniu pozytywnych wyników kontroli lekarskiej. Nie sposób jednoznacznie stwierdzić, $\mathrm{w}$ jakim stopniu $\mathrm{w}$ trakcie poboru zwracano uwagę na pochodzenie etniczne, kolor skóry, rodzaj wykształcenia czy wykonywanej pracy. Na ogół preferowano nieżonatych mężczyzn, ponieważ jak

\footnotetext{
66 Francis Bolek, Who's who in Polish America (New York: Harbinger House, 1943), 145.

67 „Polacy w Ameryce," Telegraf, lipiec 6, 1898, 1.

68 „Kronika miejscowa," Polonia w Ameryce, wrzesień 1, 1898, 4.

69 „Ochotnicy,” Kurier Polski, maj 3, 1898, 2.

70 „Czas pomyśleć," Ameryka, sierpień 12, 1893, 4.

71 „Polacy w Ameryce," Dziennik Chicagoski, listopad 14, 1898, 2.

72 Nałęcz, Polacy, 42.

73 Ibid., 30.

74 „Pierwszy strzal, Zgoda, lipiec 14, 1898, 1; „Kronika wojskowa,” Sztandar, lipiec 14, 1898, 3.

75 „Nasi żołnierze,” Dziennik Chicagoski, sierpień 31, 1898, 4. Zob. też „Powrót pierwszego pułku," 2.
} 
utrzymywano, „żonaci ochotnicy stanowiący jedyną podporę swojej rodziny nie mogą być przyjmowani, z wyjątkiem, żeby dowiedli, że familia ich w czasie ich nieobecności nie będzie pozbawiona utrzymania". ${ }^{76}$ Najwięcej osób rekrutowano z milicji stanowych, nawiązując zresztą do tradycji wojny secesyjnej, „kiedy [...] milicje pierwsze stanęły w obronie całości Stanów Zjednoczonych". ${ }^{77}$ Liczną reprezentację stanowili również strażacy oraz urzędnicy miejscy i pocztowi. ${ }^{78} \mathrm{~W}$ Milwaukee na wojnę poszło czterech pracowników redakcji Kuriera Polskiego ${ }^{79}$, w Winonie czterech zecerów Wiaru$s a^{80}$. Z Winony pochodził również Karol Ludwik, lekarz wojskowy pełniący obowiązki na polach bitewnych. ${ }^{81} \mathrm{Z}$ kolei w Detroit do wojska zaciągnął się niejaki Lucjan Koterski, student miejscowego seminarium polskiego. ${ }^{82}$ Niełatwo ustalić, ile osób polskiego pochodzenia dowodziło większą jednostką bojową niż kompania. Zagadką pozostaje postać Henryka Piotra Lewandowskiego, który mianowany przez Williama McKinleya adiutantem w randze pułkownika, mógł odegrać jakąś rolę w tej wojnie jako dowódca. Kilka lat później Theodore Roosevelt mianował go generałem adiutantem. ${ }^{83}$ W opinii komentatorów brak osób polskiego pochodzenia w kadrach dowódczych wynikał z powszechnie panującego nepotyzmu w wojsku amerykańskim. ${ }^{84}$ Zdarzały się jednak wyjątki. Błyskotliwą karierę niższego szczebla zrobił Marcin Nowak pochodzący z Cleveland. Urodził się w Stanach Zjednoczonych w 1875 r. W styczniu 1895 r. wstąpił do armii amerykańskiej. Dwa lata później został kapralem, zaś w roku 1898 sierżantem. Mając zaledwie 24 lata, doczekał się awansu na podporucznika tylko i wyłącznie wskutek nacisków obywateli Cleveland na prezydenta McKinleya, „aby dla młodego polskiego sierżanta [...] wyrobić awans". ${ }^{85} \mathrm{~W}$ Dzienniku Chicagoskim skomentowano ten fakt następująco: „Każdemu obeznanemu z wojskowymi sprawami na całym świecie, z wyjątkiem Ameryki, musi się wydawać rzeczą niemożliwą, ażeby awans jakiegokolwiek członka armii mógł

\footnotetext{
76 „Werbowanie rekrutów, Kurier Polski, czerwiec 18, 1898, 1.

77 „Gwardia Kościuszki,” Kurier Polski, wrzesień 24, 1895, 2.

78 „Miejscy ochotnicy,” Telegraf, kwiecień 27, 1898, 1.

79 Kurier Polski, czerwiec 24, 1898, 2.

80 „Wiadomości miejscowe," Wiarus, maj 12, 1898, 8.

81 „Wiadomości miejscowe," Wiarus, sierpień 18, 1898, 8.

82 „Polacy w Ameryce," Dziennik Chicagoski, sierpień 1, 1898, 2.

83 Nałęcz, Polacy, 28. Z doniesień Sztandaru wynika natomiast, że nowojorskim 7 Pułkiem Kawalerii dowodził niejaki Ludwik Dołowski, zob. „Kronika wojskowa, Sztandar, lipiec 21, 1898, 3.

84 „Polacy w Ameryce," Dziennik Chicagoski, wrzesień 9, 1899, 4.

85 „Z Cleveland,” Dziennik Chicagoski, wrzesień 18, 1899, 2.
} 
zależeć od prostego wstawienia się kilku jego przyjaciół, ludzi prywatnych i niemających wpływu w kołach wojskowych, do głowy rządu; każdemu sama myśl takiego wstawienia się dziwaczną wydać się musi. Tymczasem okazuje się, że w Stanach Zjednoczonych rzecz taka jest wielce prawdopodobna i stosunkowo łatwa".

$\mathrm{Z}$ doniesień prasowych można wnioskować, że najliczniejsze grono ochotników przynależało do niższej klasy średniej (lower middle class), jako że synowie robotników $\mathrm{z}$ reguły nie otrzymywali posad w milicji stanowej i urzędach stanowych. ${ }^{87}$ Byli to zatem ludzie, którzy mieli stosunkowo wysoką pozycję w społeczności lokalnej. Wyjątkiem od tej reguły byli ochotnicy polscy z New Jersey (ok. 800 osób), których jeśli wierzyć redaktorom Ameryki, „po większej części bezrobocie pchnęło [...] do tego czynu”.88

Może zastanawiać względnie niewielka w tym czasie aktywność polskiego Sokolstwa, skoro organizacje gimnastyczne innych grup etnicznych wykazywały stosunkowo duży zapał do walki. Szczególnie przedstawiciele formacji niemieckich i czeskich masowo zgłaszali się do punktów werbunkowych. ${ }^{89}$ Niemniej jednak, przyglądając się bliżej dziejom wewnętrznym tej instytucji w omawianym okresie, zauważyć można dotykający ją głęboki kryzys. Słabości lokalnych struktur towarzyszyły walki frakcyjne liderów, których największe nasilenie nastąpiło właśnie $\mathrm{w}$ okresie wojennego zrywu..$^{90}$ Rolę polskich Sokołów w wojnie 1898 r. zdecydowanie wyolbrzymił Stefan Barszczewski we wstępie do moralizatorsko-patriotycznej sztuki Cuba Libre, napisanej na fali fascynacji amerykańskim militaryzmem. ${ }^{91} \mathrm{O}$ udziale Sokolstwa polskiego w wojnach Ameryki tego czasu nie wspomniał inny miłośnik wojska, Artur

\section{Ibid.}

87 Z tego też powodu Gwardia Kościuszki nie cieszyła się popularnością wśród robotników, gdyż uchodziła za formację wykorzystywaną do tłumienia strajków, w których także uczestniczyli Polacy pracujący w fabrykach. „Od tego czasu coraz mniej robotników znajduje się w milicji, coraz większy [jest] przedział między klasą robotniczą a wojskiem obywatelskim” pisano w Kurierze Polskim. Sytuacja ta zatem wygenerowała podłoże do pewnego rodzaju konfliktu społecznego wewnątrz polonijnych grup, który dotychczas w oficjalnym przekazie pozostawał niewidoczny, „Gwardia Kościuszki," Kurier Polski, wrzesień 24, 1895, 2. Zob. „Nowa milicja," Telegraf, lipiec 13, 1898, 1.

88 „Polacy w Ameryce," Ameryka, maj 7, 1898, 4.

89 „Do broni,” Dziennik Chicagoski, kwiecień 25, 1898, 1; „Zapał wzrasta,” Dziennik Chicagoski, kwiecień 28, 1898, 1.

90 „Haniebny napad na redaktora naszego pisma Pana St[anisława] A. Osadę” Nowe Życie, maj 28, 1898, 1; Telegraf, lipiec 27, 1898, 2; „Popierają Sokołów, Kurier Polski, wrzesień 19, $1898,1$.

${ }_{91}$ W roku 1898 istniało ok. 20 gniazd sokolich. Według relacji Barszczewskiego w wojnie wzięła udział młodzież z Milwaukee, doprowadzając tym samym do upadku gniazda. Z kolei gniazda w Buffalo, South Bend i Chicago tylko „przerzedziły się znacznie”. O Sokołach z innych miejscowości autor nie wspomina; Barszczewski, Cuba Libre!, 3. 
Waldo, skrupulatny kronikarz i apologeta tej organizacji. ${ }^{92}$ Podobnie zresztą rzecz się miała z udziałem w działaniach wojennych członków Związku Młodzieży Polskiej. Organizację tę reprezentowali m.in. Jan Tauber oraz Stanisław Sass, piszący z obozu w Jacksonville korespondencje do Sztandaru, oficjalnego organu prasowego tej instytucji.

Kilka słów należy poświęcić obecności osób polskiego pochodzenia w najsłynniejszej formacji wojskowej tej wojny, jaką byli tzw. Rough Riders. Jednym z poległych Polaków z tego oddziału miał być niejaki Wieliński, przy którego nazwisku widniał znak zapytania, przez co redakcja Telegrafu nie była pewna, o kogo dokładnie chodzi. Podano jedynie, że jego rodzice mieszkali wówczas w nowojorskiej dzielnicy Maspeth. ${ }^{93} \mathrm{Z}$ kolei Stefan Barszczewski wymienił czterech Polaków w tym oddziale: Ignacego Zielnego, Józefa Klina, M. Ganeckiego i Grzegorza Księżpolskiego. ${ }^{94}$ Polskiego pochodzenia mogli być również Frank Kania, Joseph F. Kansky, Hyman S. Lowitzki i Hyman Rafalowitz. ${ }^{95}$

$\mathrm{Z}$ dostępnego materiału prasowego wynika, iż w szeregach armii amerykańskiej brakowało katolickich kapelanów, mimo że wielu żołnierzy deklarowało przynależność do tego wyznania. W środowiskach katolickich podejmowano na ten temat dyskusję, której echa odbijały się w czasopismach polonijnych. Członkowie jednego z towarzystw katolickich z Appleton (Wisconsin) wystosowali w tej sprawie list do gubernatora Edwarda Scofielda, pytając o powody takiego stanu rzeczy. Wymijającej odpowiedzi udzielił petentom urzędnik, zrzucając odpowiedzialność na protestanckich pułkowników. „Było dotąd zwyczajem w milicji stanowej” - wyjaśniał - „że pułkownik mianował kapelana dla swego pułku, ponieważ stosunek kapelana do pułkownika jest tak delikatnym, że gdyby zamianowano kapelana niemiłego pułkownikowi, spowodowałoby to dużo niezadowolenia i sporów". ${ }^{96}$ W Kurierze Polskim nawoływano do zmiany procedur wyboru kapelanów wojskowych. Postulowano m.in., by katolicy mieszkający w Stanach Zjednoczonych naciskali na wyższe kadry dowódcze, „, aby kapelan pułkowy nie był mianowany przez pułkownika ale przedstawiony przez większość w pułku, a zatwierdzony przez wyższe władze wojskowe, cywilne lub duchowne.". ${ }^{97}$ Niewiele pożytku przyniosły te zabiegi, podobnie jak starania o polskiego duszpasterza. O funkcję kapelana wojskowego zabiegał m.in.

\footnotetext{
92 Zob. Artur Waldo, Sokolstwo przednia straż narodu.

93 „Polacy w Ameryce," Telegraf, lipiec 6, 1898, 1.

94 Barszczewski, Cuba Libre!, 3.

95 „The Roster of 1st United States Volunteer Cavalry," Spanish American War Centennial Website, dostęp kwiecień 5, 2020, http://www.spanamwar.com/rroster.htm\#K.

96 „Kapelani wojskowi,” Kurier Polski, sierpień 13, 1898, 2.

97 Ibid.
} 
ks. Józef Ciemiński, wikary w parafii św. Stanisława w Winonie. ${ }^{98}$ Nie doczekał się jednak na wezwanie, gdyż „znalazł się w to miejsce ksiądz irlandzki". ${ }^{99}$ Wspomniany duchowny nie miał jednak wielu naśladowców. Kler, szczególnie w pierwszych tygodniach wojny, z rezerwą podchodził do konfliktu Stanów Zjednoczonych z katolickim państwem i bez przekonania angażował się w czynną służbę wojskową, nawet jeśli w oficjalnym przekazie Kościół popierał ekspansjonizm amerykański. ${ }^{100}$ Do wojaczki zniechęcały katolickich duchownych także ciężkie warunki pracy. Gdy zaś pojawiła się możliwość wysłania któregoś z księży polskich z Milwaukee jako kapelana do Jacksonville, gdzie stacjonowała Gwardia Kościuszki, przyznano, że „rozglądając się pomiędzy księżmi milwauckimi, niewielu się jednak znajdzie odpowiednich na trudy wojenne w gorącym klimacie”. ${ }^{101} \mathrm{Z}$ braku kapłana gwardziści Kościuszki chodzili na mszę odprawianą w języku angielskim przez niejakiego ks. Kenneya do miejscowego kościoła katolickiego pod wezwaniem Niepokalanego Poczęcia NMP. Kapitan Gwardii Tadeusz Wild zapewniał jednak, że w tamtejszym obozie „służba Boża odbywać się będzie regularnie co niedzielę". ${ }^{102}$ Jeśli wierzyć doniesieniom Dziennika Chicagoskiego, w 1900 r. w armii amerykańskiej służyło zaledwie 8 „urzędowo zamianowanych pensją pobierających kapelanów katolickich" - 3 z nich pełniło służbę we flocie, $5 \mathrm{w}$ siłach lądowych. ${ }^{103}$

Pamięć o wojnie amerykańsko-hiszpańskiej z roku 1898 nie przetrwała próby czasu. Duma z przynależności do zwycięskiej armii została niebawem przesłonięta doniesieniami o nowym, krwawym konflikcie rozgrywającym się na Filipinach. Działania wojenne prowadzone w tym kraju były krytycznie oceniane nie tylko przez wielu obserwatorów amerykańskiej polityki imperialnej, lecz także przez prasę polonijną, która Stany Zjednoczone postrzegała jako agresora atakującego słaby militarnie kraj walczący o niezależność.

Polskich uczestników wojny na Kubie pochowano w indywidualnych grobach. Większość z nich zresztą nie brała udziału w walkach. Świadomość faktu, że gros ofiar śmiertelnych pochłonęły choroby zakaźne, powodowała niechęć do militarnych rozwiązań i nie sprzyjała kształtowaniu martyrologicznego stosunku do sił zbrojnych. Polonia nie przywiązywała większej wagi do wojny kubańskiej także dlatego, że nie zebrała $\mathrm{z}$ niej politycznych owoców. Rok 1898 wspominano wyłącznie w niewielkim gronie

\footnotetext{
98 „Wiadomości miejscowe,” Wiarus, kwiecień 28, 1898, 8.

99 „Wiadomości miejscowe,” Wiarus, maj 12, 1898, 8.

100 Szerzej o tym zob. Matt McCullough, The Cross of War. Christian nationalism and U.S. expansion in the Spanish-American War (Madison: University of Wisconsin Press, 2014).

101 „Kapelan naszych ochotników,” Kurier Polski, maj 18, 1898, 2.

102 Wild, „Z Jacksonville," Kurier Polski, czerwiec 2, 1898, 1.

103 „Uwagi,” Dziennik Chicagoski, wrzesień 5, 1900, 2.
} 
towarzyszy broni. Po założeniu The Veterans of Foreign Wars of the United States (1899) skupiającego kombatantów wojny amerykańsko-hiszpańskiej w Chicago powstał projekt powołania do życia polskiego towarzystwa weteranów wojny kubańskiej. ${ }^{104}$ Założono je ostatecznie 1 kwietnia $1900 \mathrm{r}$. powołując na stanowisko prezesa Leona M. Nowaka, podczas gdy Teofil J. Trzebiatowski, uczestnik bitwy pod San Juan, przyjął funkcję sekretarza. ${ }^{105}$

\section{Bibliografia}

\section{Źródła drukowane}

Correspondence Relating to the War with Spain: Including in the Philippines Islands and the China Relief Expedition. T. 1. Washington: Government Printing Office, 1902.

Report of the Commission Appointed by the President to Investigate the Conduct of the War Department in the War with Spain. T. 1-8. Washington: Government Printing Office, 1900.

\section{Prasa}

Ameryka [Toledo] - 1893; 1898

Dziennik Chicagoski - 1898-1900; 1903

Echo [Buffalo] - 1898

Kurier Nowojorski - 1898

Kurier Polski [Milwaukee] - 1894-1895; 1898

Naród Polski [Chicago] - 1898

Nowe Życie [Chicago] - 1898

Ogniwo [Nowy Jork] - 1879-1880

Polak w Ameryce [Buffalo] - 1898

Polonia w Ameryce [Cleveland] - 1898

Przyjaciel Ludu [Pittsburgh] - 1893

Sztandar [Chicago] - 1898

Telegraf [Chicago] - 1898

Wiarus [Winona] - 1898

Zgoda [Chicago] - 1882; 1885; 1898

\section{Źródła literackie}

Barszczewski, Stefan. Cuba Libre! Melodramat w 5-ciu odsłonach, osnuty na tle wojny hiszpańsko-amerykańskiej i Sokolstwa Polskiego w Ameryce. Chicago: b.w., 1899.

\section{Opracowania}

Andersen, Arlow W. Rough Road to Glory. The Norwegian-American Press Speaks Out on Public Affairs, 1875 to 1925. Philadelphia: Balch Institute Press, 1990.

104 „Krótkie notatki miejskie,” Dziennik Chicagoski, marzec 21, 1900, 1; „Notatki,” Dziennik Chicagoski, marzec 29, 1900, 4.

105 Teofil J. Trzebiatowski, „Stowarzyszenie weteranów, Dziennik Chicagoski, kwiecień 4, 1900, 2. 
Bemis, Samuel F. A Diplomatic History of the United States. New York: Holt, 1963.

Bolek, Francis. Who's who in Polish America, New York: Harbinger House, 1943.

Busyn, Helen. „Peter Kiolbassa - Maker of Polish America.” Polish American Studies 8, nr 3/4 (1951): 65-84.

Dobrzycki, Wiesław. Historia stosunków międzynarodowych w czasach nowożytnych 1815-1945. Warszawa: Wyd. Naukowe Scholar, 1996.

Dyal, Donald H. Historical Dictionary of the Spanish-American War. Westport: Greenwood Press, 1996.

German, Franciszek. „Kiełbassa Piotr.” Polski Słownik Biograficzny 12, (1966-1967): 409-410.

Hicks, John D. A Short History of American Democracy. Boston: Houghton Mifflin Company, 1949.

Hofstadter, Richard. „Manifest Destiny and the Philiphines." W American Imperialism in 1898. Red. Theodore P. Greene. Boston: Heath and Company, 1955.

Jacobson, Matthew F. Special Sorrows. The Diasporic Imagination of Irish, Polish, and Jewish Immigrants in the United States. Cambridge-London: Harvard University Press, 1995.

Kłoskowicz, Robert. U.S. Marines jako narzędzie polityki zagranicznej Stanów Zjednoczonych. Kraków: Wyd. Uniwersytetu Jagiellońskiego, 2008.

Kruszka, Wacław. Historia polska w Ameryce. Początek wzrost i rozwój dziejowy osad polskich w Północnej Ameryce (w Stanach Zjednoczonych i Kanadzie). T. 7. Milwaukee: Drukiem Spółki Wydawniczej Kuriera, 1906.

LaFeber, Walter. The Cambridge History of American Foreign Relations. T. 2, The American Search for Opportunity 1865-1913. Cambridge: Cambridge University Press, 1995.

McCullough, Matt. The Cross of War. Christian nationalism and U.S. expansion in the Spanish-American War. Madison: University of Wisconsin Press, 2014.

Millis, Walter. The Martial Spirit. A Study of Our War with Spain. New York: Viking Press, 1965.

Nałęcz, Władysław. Polacy w New Yorku. Toledo: A.A. Paryski, 1910.

Olender, Piotr. Wojna amerykańsko-hiszpańska na morzu 1898 r. Warszawa: Lampart, 1995.

Pula, James S. „Kiolbassa Piotr.” W The Polish American Encyclopedia. Red. James S. Pula, s. 227. Jefferson: McFarland \& Company, Inc., Publishers, 2011.

Tompkins, E. Berkeley. Anti-Imperialism in the United States: The Great Debate 18901920, Philadelphia: University of Pennsylvania Press, 1970.

Tuchman, Barbara. Wyniosła wieża. Świat przed pierwsza wojna 1890-1914. Warszawa: Bellona, 1997.

Tucker, Spencer C., red. The Encyclopedia of the Spanish-American and Philippine Wars. A Political, Social and Military History. T. 1-3. Santa Barbara: ABC-CLIO, 2009.

Waldo, Artur. Sokolstwo przednia straż narodu. Dzieje idei i organizacji w Ameryce. T. 1-4. Pittsburgh: Sokolstwo Polskie w Ameryce, 1953-1974.

Weinberg, Albert K. Manifest Destiny. A Study of Nationalist Expansionism in American History. Chicago: Quadrangle Books, 1963.

Wind, Bogusław W. Santiago 1898. Warszawa: Bellona, 1995. 


\section{Internet}

„Spanish-American War Service Record Index.” Fold3 . Dostęp listopad 14, 2020. https://www.fold3.com/browse/hyABSb3KgLle5B31pgnfgkQ11.

„The Roster of 1st United States Volunteer Cavalry." Spanish American War Centennial Website. Dostęp kwiecień 5, 2020. http://www.spanamwar.com/rrroster. htm\#K.

\section{STRESZCZENIE}

\section{Daniel Kiper, Polacy w armii amerykańskiej podczas konfliktu zbrojnego na Kubie w 1898 r. (szkic problemu)}

Artykuł podejmuje problem udziału polskich imigrantów w USA w konflikcie zbrojnym na Kubie w 1898 r. Wojna amerykańsko-hiszpańska w zasadniczy sposób wpłynęła na zachowania społeczne przedstawicieli grup etnicznych osiedlonych na terytorium Stanów Zjednoczonych. W przeważającej części imigranci pochodzenia europejskiego popierali imperialne aspiracje Ameryki i chętnie wstępowali do armii. Należeli do nich Polacy, przedstawiciele pierwszego i drugiego pokolenia emigracji ekonomicznej. Tocząca się wojna dała im okazję do potwierdzenia swojej lojalności wobec Stanów Zjednoczonych i osiągnięcia korzyści dla własnej grupy etnicznej. Przy obecnym stanie badań możemy jedynie w dużym przybliżeniu oszacować liczbę Polaków biorących udział w wojnie amerykańsko-hiszpańskiej. Wiele informacji na ten temat znajduje się w ówczesnej prasie polonijnej, na podstawie której starano się zarysować ogólny obraz okoliczności poboru Polaków do armii amerykańskiej oraz niektóre kwestie związane m.in. z karierami wojskowymi, duszpasterstwem wojskowym, zbiorową pamięcią o wojnie.

Słowa kluczowe: wojna amerykańsko-hiszpańska, Polacy w Stanach Zjednoczonych, XIX wiek

\section{SUMMARY}

\section{Daniel Kiper, Poles in the US Army during the Armed Conflict in Cuba in 1898 (an Outline of the Problem)}

The article deals with the problems associated with Polish immigrants who served in the US Army during the armed conflict in Cuba in 1898. The American-Spanish war had a fundamental influence on the social behavior of ethnic groups that had settled in the United States. For the most part, immigrants of European descent, including first and second generation Polish economic migrants, supported America's imperial aspirations and willingly joined the army. The ongoing war gave them an opportunity to reaffirm their loyalty to the United States and gain benefits for their own ethnic group. Due to the current state of research, we can only roughly estimate the number of Poles involved in the 
Spanish-American war. A variety of articles concerning the subject appeared in the contemporary Polish press, based on which attempts were made to outline the general circumstances behind Polish recruitment into the US Army as well as other issues related to, inter alia, military careers, military pastoral care, a collective memory of the war.

Keywords: Spanish-American War, Poles in the United States, 19th century

\section{АННОТАЦИЯ \\ Даниэль Кипер, Поляки в американской армии во время вооруженного конфликта на Кубе в 1898 г. (эскиз проблемы)}

В статье рассматривается проблема участия польских выходцев из США в вооруженном конфликте на Кубе в 1898 г. Американо-испанская война оказала серьезное влияние на социальное поведение представителей этнических групп, осевших на территории США. По большей части иммигранты европейского происхождения поддерживали имперские устремления Америки и охотно вступали в армию. К ним принадлежали и поляки, представители первого и второго поколения экономической эмиграции. Война дала им возможность подтвердить свою лояльность Соединенным Штатам и извлечь выгоду для своей этнической группы. При нынешнем состоянии исследований мы можем лишь приблизительно оценить количество поляков, участвовавших в испано-американской войне. В то время в прессе польской диаспоры было много информации по этому поводу, на основании которой были предприняты попытки очертить общую картину обстоятельств призыва поляков в американскую армию и некоторые вопросы, связанные с этим, среди которых: военная карьера, деятельность религиозных организаций, связанных с армией, и коллективная память о войне.

Ключевые слова: испано-американская война, поляки в США, XIX век 